\title{
REPRODUCTIVE PARAMETERS OF PORCELLIUM COLLICOLA (VERHOEFF, 1907) AND TRACHELIPUS ARCUATUS (BUDDE- LUND, 1885) (CRUSTACEA: ISOPODA: ONISCIDEA) IN SOUTH ROMANIA
}

\author{
FINICA MARIANA IVANOV
}

\begin{abstract}
Porcellium collicola (Verhoeff, 1907) and Trachelipus arcuatus (Budde-Lund, 1885) (Crustacea: Isopoda: Oniscidea) are two terrestrial isopod species inhabiting the leaf litter of oak forests in South Romania. This paper presents the size of reproductive females, fecundity (the number of eggs for a female for a brood), fertility (the number of larvae or mancas per female) and the relationship between the number of eggs or mancas per brood pouch and the total body length of pregnant females. In Porcellium collicola populations' reproductive females had a total body length of 3.3 to $7.3 \mathrm{~mm}$, average fecundity was $18.60 \pm 7.10$ eggs per female and average number of mancas per female was $10.29 \pm 8.05$. In Trachelipus arcuatus the total body length of reproductive females was between $9.80-16.60 \mathrm{~mm}$ and the average number of eggs per brood per female was $55.60 \pm 21.71$. A direct correlation between the size of pregnant females and fecundity and fertility was established for Porcellium collicola.
\end{abstract}

Résumé. Porcellium collicola (Verhoeff, 1907) et Trachelipus arcuatus (Budde-Lund, 1885) sont deux espèces d'isopodes terrestres de la litière des forèts de chènes dans le sud de la Roumanie. Ce travaille présente les dimensions du corps des femelles ovigères, fécondité (le nombre d'œufs d'une femelle dans la poch marsupiale), fertilité (le nombre de larves ou manca par une femelle) et la relation entre le nombre d'œufs ou de larves (manca) de leur poche marsupiale et la longueur du corps des femelles ovigères. Chez Porcellium collicola, les populations de femelles reproductives ont une longueur totale de 3,3 à 7,3 mm, fécondité moyenne était 18,60 7,10 œufs par femelle et nombre moyen de mancas par femelle était 10,29 $\pm 8,05$. Chez Trachelipus arcuatus la longueur totale du corps des femelles reproductrives était compris entre 9,80 à 16,60 $\mathrm{mm}$ et le nombre moyen d'œufs

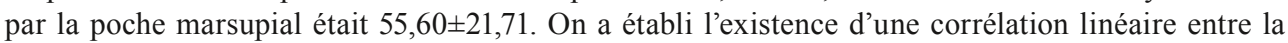
longueur du corps des femelles ovigères et la fécondité et la fertilité Porcellium collicola.

Key words: terrestrial isopods, fecundity, fertility, leaf-litter, oak forests.

\section{INTRODUCTION}

Terrestrial isopods are crustaceans that successfully colonized a variety of terrestrial habitats (e.g. Hornung, 1995/1996, 2011; Quadros et al., 2009; Warburg, 1987). The middle-east European species are mainly iteroparous animals, reproducing more then once during their lifetime (Hornung, 1988). Fecundity and fertility of terrestrial isopods are easy to estimate because females carry their eggs and larvae from the first stage in a brood pouch on the ventral part of the thorax during the breeding period (Hornung, 2011; Kight, 2008; Paris \& Pitelka, 1962; Warburg, 1987). Fecundity is defined as the number of eggs for a female for one 
brood (Achouri et al., 2008; Hamaied \& Charfi-Cheikhrouha, 2004; Quadros et al., 2009). Fertility is the number of juveniles (mancas) leaving the brood pouch per female (Achouri et al., 2008). Fecundity indicates the reproductive potential of a population, while fertility expresses the natural capacity of a population to produce new life forms.

In terrestrial isopods, fecundity is related to the size of the ovigerous females (Achouri et al., 2008; Dangerfield \& Hassall, 1992; Hornung, 1988; Lawlor, 1976; Quadros et al., 2009; Radu \& Tomescu, 1972; Zimmer, 2002; Warburg, 1994) and the number of broods produced by female per year (Accola et al., 1993; Radu \& Tomescu, 1971; Tomescu, 1973, 1976). Fertility of terrestrial isopods is also related to the size of the reproductive females (Warburg, 1994).

This paper presents the size of reproductive females, fecundity, fertility and the relationship between the size of pregnant females and the number of eggs or mancas per brood pouch for the populations of two terrestrial isopod species Porcellium collicola and Trachelipus arcuatus that inhabit the leaf-litter of two oak forests from Vlăsia plain (South Romania). We assumed that fecundity and fertility of the studied terrestrial isopod species depend on the total body length of pregnant females.

\section{MATERIAL AND METHODS}

Study site and sampling design

The study was conducted in two oak forests (in the forest steppe of Vlăsia plain), located at $20 \mathrm{~km} \mathrm{~N}$-E from București (Bucharest) (Fig. 1): a Quercus frainetto wood (Moara Vlăsiei forest) and a Quercus robur - Q. pedunculiflora wood (Brânzeasca forest) (Doniţă et al., 1990). The studied area is located in a medium flat plain at an elevation of 90 meters above sea level. The climate is continental, with warm summers (average temperature in July is $23^{\circ} \mathrm{C}$ ) and cold winters (average temperature in January is $2.9^{\circ} \mathrm{C}$ ). The mean annual precipitation is $550 \mathrm{~mm}$ and the distribution of average monthly precipitation has a minimum in February-March and October-November and a maximum in June. The type of soil is clay chernozem in Brânzeasca forest and cambic chernozem in Moara Vlăsiei forest.

Four stands (units of forest mapping) were selected in studied forests; within each of them, five areas of 10 square meters, named stations, were randomly chosen: two in Brânzeasca forest (stations 1 and 2) and three in Moara Vlăsiei forest (stations

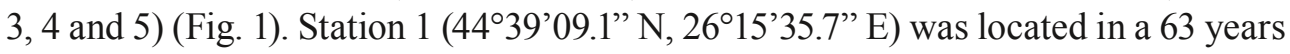
native stand with the tree layer composed of Quercus frainetto, $Q$. pedunculiflora and Acer platanoides. The shrub layer consisted of Crataegus monogyna and Cornus sanguinea, and the herbaceous layer was composed of Galium aparine, Urtica dioica, Lamium album, Alliaria officinalis and Polygonatum officinale. Station $2\left(44^{\circ} 38^{\prime} 52.7^{\prime \prime} \mathrm{N}, 26^{\circ} 15^{\prime} 18.7^{\prime \prime}\right.$ E) was situated in a 30 years plantation of Quercus pedunculiflora and Acer platanoides. The shrub layer consisted of Cornus 


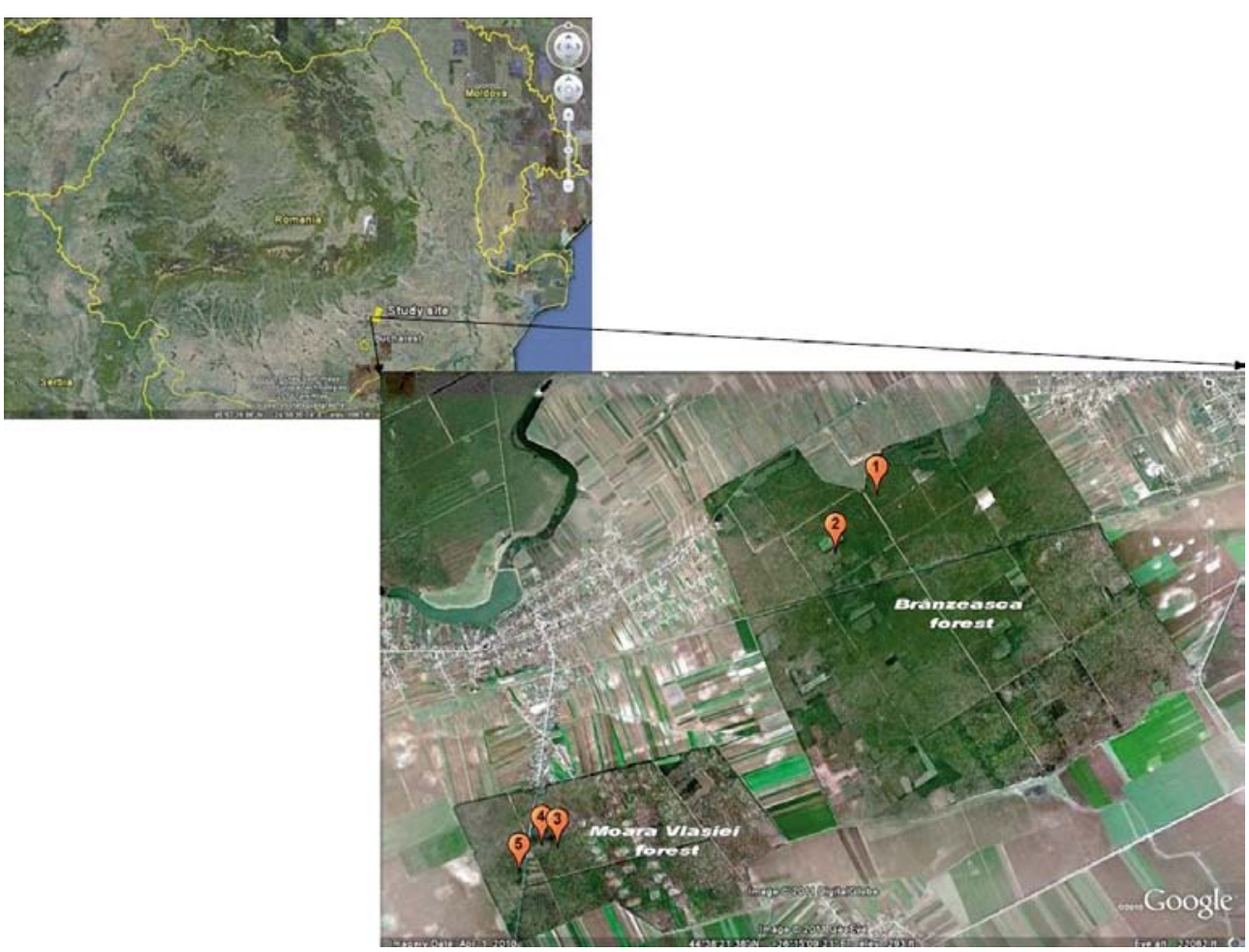

Fig. 1 - Location of the study site in Romania and stations in studied forests (adapted from Google Earth).

sanguinea, and the herbaceous layer was composed of Geum urbanum, Bromus sterilis and Lysimachia vulgaris. Station 3 (4437'28.4” N, 26 13'24.9”' E) was located in an 81 years native stand with the tree layer composed of Quercus pedunculiflora, Q. robur and different species of hard wood (maple, hornbeam, etc.). The shrub layer consisted of Crataegus monogyna and Cornus sanguinea, and the herbaceous layer was composed of Galium aparine, Lamium album and Polygonatum officinale. Station 4 (44³7'29.2" N, 26 $13^{\circ} 18.6^{\prime \prime}$ E) was placed in the preceding stand, in an area subjected for almost 10 years to progressive cutting of Quercus robur. To ensure statistical independence of the data, station 4 was distanced at more then 50 meters from station 3 (Magura et al., 2000). Station 5 (44³7’21.3” N, 26¹3’09.3” E) was located in a 65 years native stand with the tree layer composed of Quercus pedunculiflora, Q. robur and Q. frainetto. The shrub layer consisted of Crataegus monogyna and Cornus sanguinea, and the herbaceous layer was composed of Galium aparine, Geum urbanum and Erodium cicutarium. The distance between the sampling areas from the two studied forests was approximately 4 km (Fig. 1). 
Terrestrial isopod species were collected using pitfall traps containing a mixture of $3 / 440 \%$ ethylene glycol and $1 / 44 \%$ formalin. In each station ten pitfall traps were placed in a grid, with a 1.5 meters distance between the lined traps. Traps were emptied monthly from the 20th of April 2008 to the 7th of May 2009 (except for December 2008 and January 2009).

\section{Laboratory procedures}

Isopods from samples were counted and identified using the keys of Radu (1985) and Schmidt (1997). Specimens were sexed and separated into males and females. Males were recognized by the presence of genital apophyses and copulative stylets. Females were divided into three groups: (1) non-reproductive females, recognized by the absence of genital apophyses and brood pouch, (2) ovigerous females, that were carrying eggs or larvae (mancas) in the brood pouch and (3) post-ovigerous females that had empty brood pouch (Achouri et al,. 2003; Araujo \& Bond-Buckup, 2005; Hamaied \& Charfi-Cheikhrouha, 2004).

The eggs or mancas found in the brood pouches of ovigerous females were gently removed and counted. These data allowed quantifying fecundity and fertility.

Using a stereo microscope, the total length of ovigerous females were measured to the nearest $0.05 \mathrm{~mm}$. The length was determined as the distance between median lobe of the head and the tip of the pleotelson (Achouri et al., 2003; Paris \& Pitelka, 1962).

\section{Data analysis}

The relationship between the number of eggs or mancas per brood pouch and the total body length of ovigerous females were described using simple linear regression (Achouri et al., 2003, 2008; AlJetlawi \& Achuthan Nair, 1994; Paris \& Pitelka, 1962). Results were considered statistically significant if the calculated value of the probability to reject the null hypothesis was less than 0.05 . The analyses were implemented using Microsoft Excel program.

\section{RESULTS AND DISCUSSIONS}

In the five stations of the study sites only two species of terrestrial isopods were collected by pitfall trapping: Porcellium collicola (Verhoeff, 1907) and Trachelipus arcuatus (Budde-Lund, 1885). Porcellium collicola was present in captures from all stations (Tab. 1). It is a sylvan species that is present in forests with a dense shrub layer (Tomescu et al., 1992) and high soil humidity (Tomescu et al., 1995, 2008). In the studied zone $P$. collicola had the highest abundance in station 3 (Tab. 1) that was placed in the native forest stand with the most dense shrub layer and the highest canopy closure. Trachelipus arcuatus was collected mainly from station 2 (Tab. 1) located in a plantation from the same forest as station 1. It is also a sylvan species (Tomescu et al., 2000, 2005, 2008) but is less frequent in leaf-litter (Radu, 1985; Tomescu et al., 2008) and prefers areas with moderate light and humidity, as glades (Radu, 1985). The presence of T. arcuatus mostly in station 2 may be related 
to microclimate conditions on the forest floor in forest plantations that are similar to those from glades, as a consequence of a simplified structure of the phytocenosis and a reduced closure of the canopy.

Table 1

The total number of Porcellium collicola and Trachelipus arcuatus specimens collected in studied plots.

\begin{tabular}{|l|r|r|r|r|r|}
\hline \multicolumn{1}{|c|}{ Species } & \multicolumn{1}{|c|}{ Station 1 } & \multicolumn{1}{c|}{ Station 2 } & \multicolumn{1}{c|}{ Station 3 } & \multicolumn{1}{c|}{ Station 4 } & \multicolumn{1}{c|}{ Station 5 } \\
\hline Porcellium collicola & 1693 & 26 & 2052 & 793 & 494 \\
\hline Trachelipus arcuatus & 2 & 51 & 0 & 2 & 0 \\
\hline Total & 1695 & 77 & 2052 & 795 & 494 \\
\hline
\end{tabular}

\section{The size of reproductive females}

We determined the minimum, maximum and median body length of reproductive (ovigerous and post-ovigerous) Porcellium collicola females in stations $1,3,4$, and 5 , from which a large number of specimens were collected, by examining 1145 specimens (612 in station 1, 397 in station 3, 136 in station 4 and 139 in station 5). Size of females at sexual maturity was estimated as the minimum body length of ovigerous females.

Reproductive females of $P$. collicola had a body length of 3.3 to $7.3 \mathrm{~mm}$, with a median of $5.05 \mathrm{~mm}$. The minimum body length of sexually mature $P$. collicola females varied in studied populations between 3.30 and $4.35 \mathrm{~mm}$. Dangerfield and Hassall (1992) also found a variation in the minimum size of gravid female (mean live mass) between different populations of Armadillidium vulgare. The variation of the reproductive female' minimum body length may be explained by the existence of different growth rates in terrestrial isopod populations from habitats with different ecological conditions. Kight (2008) argued that two genetically identical females reared in different growth conditions could have different adult body size. The ovigerous females of $P$. collicola had the highest minimum body length $(4.35 \mathrm{~mm})$ in station 3 located in the natural forest stand with the most dense shrub layer and the highest canopy closure. This suggests the existence of more favorable microclimate conditions on the forest floor of this stand for $P$. collicola and is supported by the highest abundance of the species in station 3 (Tab. 1). In terrestrial isopods, females have to reach a minimum reproductive size (Caubet, 1998) that depends on tactics of individual development and growth conditions experienced by the individuals (Dangerfield \& Hassall, 1992; Zimmer, 2004).

In Trachelipus arcuatus we determined the minimum, maximum and median body length of reproductive females by examining 20 specimens collected in station 2. Breeding females of T. arcuatus had a body length between 9.80 and $16.60 \mathrm{~mm}$, with a median of $11.10 \mathrm{~mm}$. There are no data regarding the size of the reproductive females of Porcellium collicola and Trachelipus arcuatus in the literature. 
Fecundity and fertility

In Porcellium collicola we quantified fecundity and fertility by counting the eggs or mancas in the brood pouch of ovigerous females captured in stations 1, 3, 4, and 5 during the entire study. In Trachelipus arcuatus we quantified only fecundity because no females with mancas in their brood pouch were captured in the studied area.

The number of eggs for a brood was different for all four analyzed $P$. collicola populations (stations 1, 3, 4, and 5). In terrestrial isopods, the number of eggs produced per brood generally varies with the size of females (Paris \& Pitelka, 1962), but there are also exceptions (Radu \& Tomescu, 1972). The number of $P$. collicola pregnant females collected in each station, their minimum and maximum body length, and minimum, average $( \pm \mathrm{SE})$ and maximum number of eggs per brood are presented in tab. 2.

Table 2

Reproductive parameters of Porcellium collicola populations in stations 1, 3, 4, and 5.

\begin{tabular}{|c|r|r|r|r|r|r|}
\hline Station & $\begin{array}{c}\text { Number of } \\
\text { pregnant } \\
\text { females }\end{array}$ & $\begin{array}{c}\text { Minimum } \\
\text { body length } \\
(\mathrm{mm})\end{array}$ & $\begin{array}{c}\text { Maximum } \\
\text { body length } \\
(\mathrm{mm})\end{array}$ & $\begin{array}{c}\text { Minimum eggs } \\
\text { number per } \\
\text { brood }\end{array}$ & $\begin{array}{c}\text { Maximum eggs } \\
\text { number per } \\
\text { brood }\end{array}$ & $\begin{array}{c}\text { Average number } \\
\text { of eggs ( } \pm \text { SE) per } \\
\text { brood }\end{array}$ \\
\hline 1 & 325 & $4.00-4.95$ & 6.10 & 5 & 31 & $15.22 \pm 5.05$ \\
\hline 3 & 215 & 4.60 & 7.05 & 5 & 54 & $23.27 \pm 7.30$ \\
\hline 4 & 72 & 4.40 & 6.05 & 5 & 35 & $18.63 \pm 6.63$ \\
\hline 5 & 60 & $4.95-5.60$ & 6.35 & 9 & 36 & $20.15 \pm 6.48$ \\
\hline
\end{tabular}

In terrestrial isopods, the average number of eggs per brood pouch may depend upon the species and locality (Hamaied \& Charfi-Cheikhrouha, 2004; Kight, 2008) and also on habitat and within-habitat level (Oberfrank et al., 2011). In the case of a species, brood size is connected to life-history strategies, but is influenced by climatic conditions: light intensity, day length, temperature, etc. and habitat parameters: microclimate, vegetation, shelter sites, etc. (Hornung, 1988; Kight, 2008; Oberfrank et al., 2011). In P. collicola populations from studied forests, fecundity varied between 5 and 54 eggs per brood per female. A variation in brood size between populations was also found in Armadillidium vulgare (Kight, 2008). The variation of terrestrial isopods' fecundity might be explained by a combination of factors influencing individual growth and ecophysiology: the genetic determinant of the growth rate, the ability of individuals to utilize resources, the given environmental conditions, the birth date in seasonal environments, the timing of allocation of resources to reproduction, the timing within the temporal sequence of reproductive events in the case of iteroparous species (Achouri et al., 2003; Hamaied \& Charfi-Cheikhrouha, 2004).

The average number of $P$. collicola eggs' $( \pm \mathrm{SE})$ for a brood of a female in the analyzed stations is presented in tab. 2. In the study zone (combined samples from all stations) the average number of eggs ( \pm SE) per brood per female was $18.60 \pm 7.10$, and the body length of ovigerous females carrying eggs in their brood pouch varied 
between 3.85 and $6.80 \mathrm{~mm}$. There are no data regarding fecundity of $P$. collicola

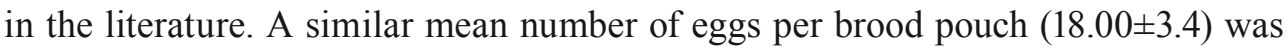
found in Porcellionides pruinosus (Hamaied \& Charfi-Cheikhrouha, 2004). Smaller values of the mean number of eggs per brood pouch were reported: $11 \pm 4$ eggs per female for Atlantoscia floridana (Araujo \& Bond-Buckup, 2005), 15 eggs per female for Hyloniscus transsylvanicus (Tomescu, 1976), 17 eggs (Radu \& Tomescu, 1972) or 17 - 32 eggs per female depending on time for Protracheoniscus politus (Hornung, personal communication; Oberfrank et al., 2011). Higher values were reported for Trachelipus nodulosus (23 eggs per female) (Hornung, 1988), Armadillo officinalis (25 eggs per female) (AlJetlawi \& Achuthan Nair, 1994), Armadillidium pelagicum (50.91 \pm 14.30 eggs per females) (Hamaied \& Charfi-Cheikhrouha, 2004).

In Trachelipus arcuatus fecundity was quantified by counting eggs in the brood pouches of 10 ovigerous females collected in the study plots. The number of eggs per brood pouch varied between 33 eggs in a female with body length of 11.90 $\mathrm{mm}$ and 110 eggs in a female with body length of $15.00 \mathrm{~mm}$. The average number of eggs $( \pm \mathrm{SE})$ for a brood in a female was $55.60 \pm 21.71$. There are no data regarding fecundity of T. arcuatus in the literature.

In terrestrial isopods, the number of eggs per brood per female is in close linear correlation with the size of pregnant females (Hornung, 1988). Using simple linear regression, we described the relation between the number of eggs per brood pouch and the female's body length for both isopod species. In Porcellium collicola we described this relation for stations 1, 3, 4, and 5 and for the study zone (combined samples from all stations).

The simple linear regression indicated a significant linear correlation between the number of eggs in the brood pouch and the body length of $P$. collicola females in station $1(\mathrm{r}=0.741, \mathrm{p}<0.0001)$, station $3(\mathrm{r}=0.783, \mathrm{p}<0.0001)$, station $4(\mathrm{r}=0.728, \mathrm{p}<0.0001)$, station $5(\mathrm{r}=0.660, \mathrm{p}<0.0001)$ and for the study zone $(\mathrm{r}=$ $0.816, \mathrm{p}<0.0001)$. The relation between the number of eggs and the female's body length, along with the coefficient of determination $\left(\mathrm{r}^{2}\right)$ are presented in figures 2 and 3. Thus, we established the existence of a linear correlation between fecundity and the body length of $P$. collicola females in studied forests. This phenomenon is common in terrestrial isopod species (AlJetlawi \& Achuthan Nair, 1994).

We also established a significant correlation $(r=0.851, p=0.0009)$ between the number of eggs in the brood pouch and the body length of Trachelipus arcuatus females, although the linear regression model was based only on 10 specimens. The relation between the number of eggs and the females' body length, along with the coefficient of determination $\left(\mathrm{r}^{2}\right)$ are presented in fig. 4. These results confirm the underlying study hypothesis according to which fecundity of the studied terrestrial isopod species depends on the total body length of pregnant females.

A direct correlation between the number of eggs in the brood pouch and the female's body length was also identified in Armadillidium vulgare (Miller \& Cameron, 1983; Paris \& Pitelka, 1962; Tomescu et al., 1992), Trachelipus nodulosus 

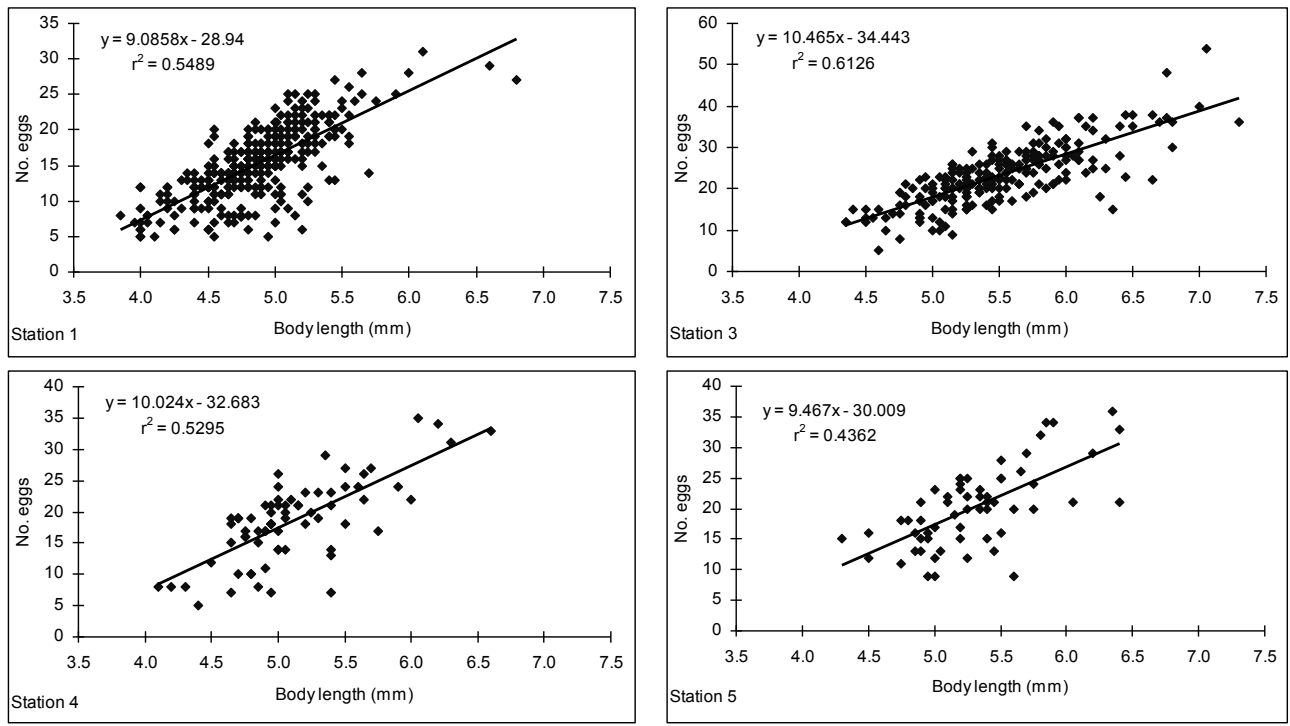

Fig. 2 - The relationship between the number of eggs per brood and the body length of Porcellium collicola females in stations $1,3,4$, and 5 .

(Hornung, 1989; Tomescu et al., 1992), Armadillidium versicolor, Ligidium hypnorum, Protracheoniscus politus (Tomescu et al., 1992), Trachelipus difficilis rotundatus (Accola et al., 1993; Tomescu et al., 1992), Cylisticus convexus (Hatchett, 1947 in Paris \& Pitelka, 1962), Porcellio scaber (Brereton, 1956 in Paris \& Pitelka, 1962; Tomescu \& Crăciun, 1987), Porcellionides pruinosus (Achouri et al., 2003, 2008), Armadillo officinalis (AlJetlawi \& Achuthan Nair, 1994), Agabiformius lentus, Porcellio laevis, P. dalensis, Armadillidium granulatum, Soteriscus gaditanus, Porcellionides sexfasciatus (Achouri et al., 2008). In some isopod species direct correlations were identified between fecundity and other parameters

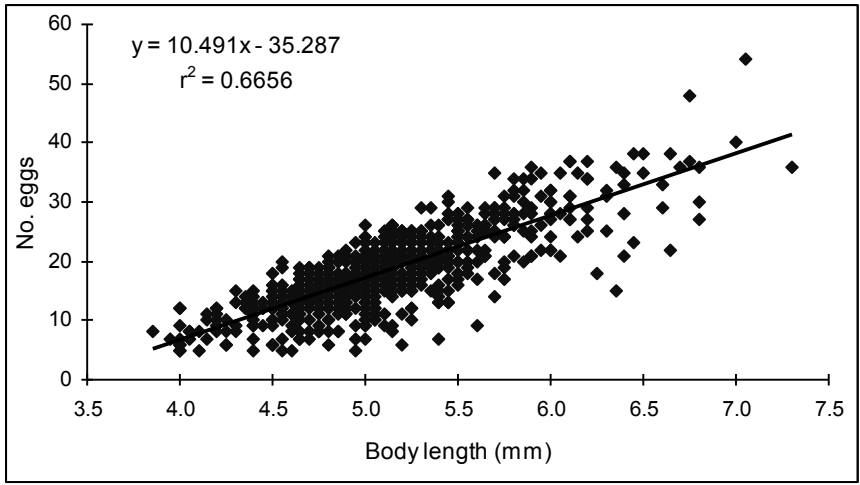

Fig. 3 - The relationship between the number of eggs per brood and the body length of Porcellium collicola females in the study zone. 


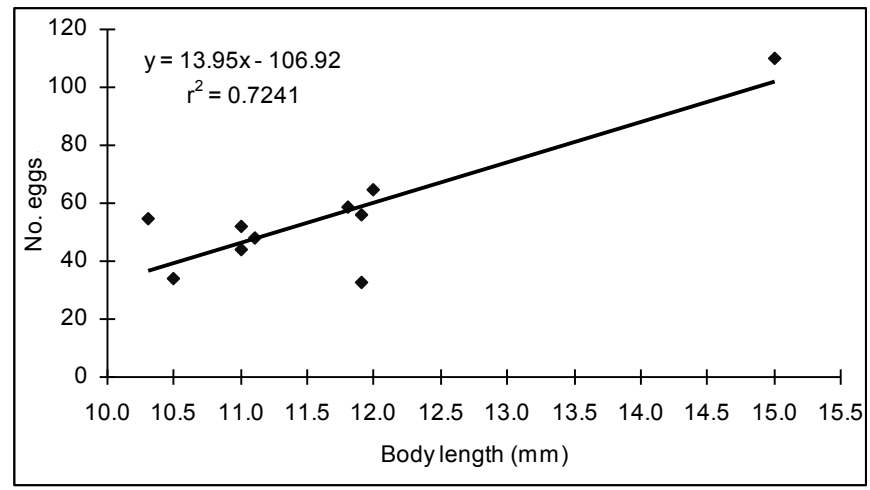

Fig. 4 - The relationship between the number of eggs per brood and the body length of Trachelipus arcuatus females in the study zone.

of ovigerous females, as the body weight in Armadillidium pelagicum (Hamaied \& Charfi-Cheikhrouha, 2004) and Porcellio laevis (Lardies et al., 2004) or the cephalothorax width in Atlantoscia floridana (Araujo \& Bond-Buckup, 2005). In terrestrial isopods, large females produce larger number of eggs per brood then the small ones. Therefore the birth rate in populations is related not only to the number of reproductive females, but also to their size at reproduction (Hamaied \& CharfiCheikhrouha, 2004).

The number of mancas found in marsupial pouch of Porcellium collicola pregnant females varied between 2 and 28, and the average number of mancas $( \pm \mathrm{SE})$ per female was $10.29 \pm 8.05$. Pregnant females carrying mancas in their brood pouch had a body length of 4.35 to $7.00 \mathrm{~mm}$. A wide range of the number of young released from the marsupial pouch (from 7 to 36) was also found in a tropical population of Porcellionides pruinosus (Dangerfield \& Telford, 1990). From the 21 analyzed $P$. collicola females 12 were carrying less then 10 mancas per marsupial pouch. The low number of mancas per female may be the result of their expulsion from the brood pouch when females impacted the liquid from the trap. This is supported by the presence of free mancas and females with open marsupial pouch and few mancas in trapped material. Araujo and Bond-Buckup (2005) found that females of Atlantoscia floridana move heavily and expel the marsupial content when they contact the ethanol during Berlese funnel extraction.

Linear regression indicated a significant correlation $(r=0.507, p=0.016)$ between fertility and size of Porcelium collicola females. The relation between the number of mancas per brood pouch and the female's body length, along with the coefficient of determination $\left(\mathrm{r}^{2}\right)$ are presented in fig. 5. Thus, we established the existence of a linear correlation between fertility and body length of $P$. collicola females in studied forests. These also confirm the underlying study hypothesis according to which fertility of the studied terrestrial isopod species depends on the size of pregnant females. 


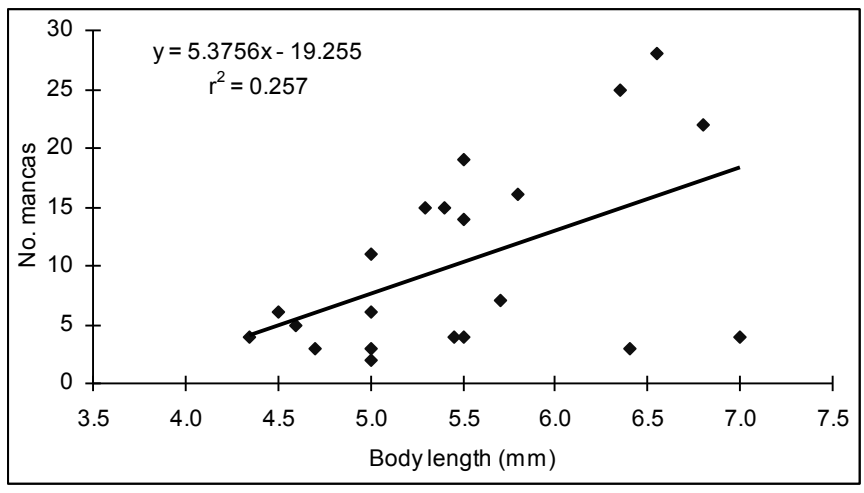

Fig. 5 - The relationship between the number of mancas per brood pouch and the body length of Porcellium collicola females in the study zone.

A similar relation between fertility and female's size was observed in other terrestrial isopod species. Achouri et al. (2003) showed a significant correlation between the number of hatched embryos found in marsupial pouch and the female's body length in Porcellionides pruinosus. AlJetlawi and Nair (1994) found a positive correlation between the number of young liberated by females and females' body length in Armadillo officinalis. Dangerfield and Telford (1990) found a positive relationship between the body mass of female and the number of young released from the brood pouch. Miller and Cameron (1983) showed the existence of a significant relation between isopods' size and the number of larvae in the marsupial pouch in Armadillidium vulgare.

\section{ACKNOWLEDGEMENTS}

The author is very grateful to Dr. Elisabeth Hornung (Budapest, Hungary), Dr. Ferenc Vilisics (Budapest, Hungary) and Dr. Helmut Schmalfuss (Stuttgart, Germany) for revising identifications, to Dr. Elisabeth Hornung, Dr. Christian Schmidt (Bochum, Germany) and Dr. Nicolae Tomescu (Cluj, Romania) for the literature sources they sent, and also to Dr. Elisabeth Hornung for her helpful comments and useful suggestions that help me improve the previous version of the manuscript.

\section{PARAMETRII REPRODUCERII LA SPECIILE PORCELLIUM COLLICOLA (VERHOEFF, 1907) ŞI TRACHELIPUS ARCUATUS (BUDDE-LUND, 1885) (CRUSTACEA: ISOPODA: ONISCIDEA) DIN SUDUL ROMÂNIEI}

\section{REZUMAT}

Porcellim collicola (Verhoeff, 1907) şi Trachelipus arcuatus (Budde-Lund, 1885) sunt două specii de izopode terestre care trăiesc în litiera pădurilor de stejar din câmpia Vlăsiei (sudul României). Acest articol prezintă mărimea corpului femelelor reproducătoare, fecunditatea (numărul de ouă per pontă per femelă), fertilitatea (numărul de larve sau manca per femelă) şi relaţia dintre numărul de ouă sau manca per pungă incubatoare şi lungimea totală a corpului femelelor purtătoare de ouă sau larve. În populaţiile de Porcellium collicola femelele reproducătoare au avut o lungime totală a corpului de $3,3-7,3 \mathrm{~mm}$, fecunditatea medie a fost de $18,60 \pm 7,10$ ouă per femelă, iar

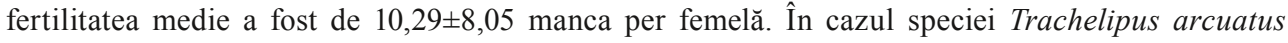


lungimea totală a corpului femelelor reproducătoare a fost cuprinsă între 9,8 şi 16,6 mm, iar numărul

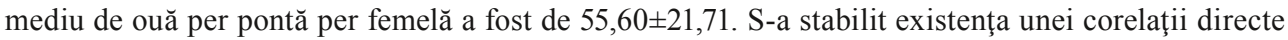
între mărimea corpului femelelor purtătoare de ouă sau manca şi fecunditate, respectiv fertilitate la specia Porcellium collicola.

\section{LITERATURE CITED}

ACCOLA, S., N. TOMESCU, C. BERCIU, C. RUSU, 1993 - The reproduction of Trachelipus difficilis rotundatus Radu, 1950 (Crustacea: Isopoda). Revue Romaine de Biologie, Biologie Animale, 38: 115-121.

ACHOURI, M. S., F. CHARFI-CHEIKHROUHA, J. C. MARQUES, 2003 - Biology, population structure, and field-growth rates of Porcellionides pruinosus (Brandt, 1833) (Isopoda, Oniscidea) at Garat Nâam (Kasserine, Tunisia). Crustaceana, 75 (10): 1241-1262.

ACHOURI, M. S., F. CHARFI-CHEIKHROUHA, M. ZIMMER, 2008 - Reproductive patterns in syntopic terrestrial isopod species (Crustacea, Isopoda, Oniscidea) from Morocco. Pedobiologia, 52: 127-137.

ALJETLAWI, A. A., G. ACHUTHAN NAIR, 1994 - Breeding and population biology of Armadillo officinalis (Isopoda: Oniscidea) in Benghazi, Libya. Journal of Arid Environments, 27 (3): 241-255.

ARAUJO, P. B., G. B. BOND-BUCKUP, 2005 - Population structure and reproductive biology of Atlantoscia floridana (van Name, 1940) (Crustacea, Isopoda, Oniscidea) in southern Brazil. Acta Oecologica, 28: 289-298.

CAUBET, Y., 1998 - Individual life histories in terrestrial isopod populations: A simulation program. Israel Journal of Zoology, 44 (3-4): 423-437.

DANGERFIELD, J. M., M. HASSALL, 1992 - Phenotypic variation in the breeding phenology of the woodlouse Armadillidium vulgare. Oecologia, 89: 140-146.

DANGERFIELD, J. M., S. R. TELFORD, 1990 - Breeding phenology, variation in reproductive effort and offspring size in a tropical population of the woodlouse Porcellionides pruinosus. Oecologia, 82: 251-258.

DONIŢĂ, N., C. CHIRIŢĂ, V. STĂNESCU (eds), 1990 - Tipuri de ecosisteme forestiere din Romania [Types of forest ecosystems in Romania]. Pp. 283-285, 308-309. Institutul de Cercetări şi Amenajări Silvice, Seria a-II-a, București. (in Romanian)

HAMAIED, S., F. CHARFI-CHEIKHROUHA, 2004 - Life cycle and population dynamic of Armadillidium pelagicum Arcangeli, 1955 (Isopoda, Oniscidea) at Aouina. Comptes Rendus Biologies, 327: 343-352.

HORNUNG, E., 1988 - Preliminary data to the clutch-size of Trachelipus nodulosus C. L. Koch in different habitats. Acta Biologica Szegediensis, 34: 169-171.

HORNUNG, E., 1989 - Population dynamics and spatial distribution of Trachelipus nodulosus (C. L. Koch, 1838) (Crustacea: Isopoda) in a sandy grassland. Monitore Zoologico Italiano, 4: 399-409.

HORNUNG, E., 1995/1996 - Reproductive strategies and spatio-temporal patterns of terrestrial isopod populations - Summary of thesis submitted for the degree of Candidate of Science. Acta Biologica Szegediensis, 41: 119-122.

HORNUNG, E., 2011 - Evolutionary adaptation of oniscidean isopods to terrestrial life: Structure, physiology and behaviour. Terrestrial Arthropods Reviews, 4 (2): 95-130.

KIGHT, S. L., 2008 - Reproductive ecology of terrestrial isopods (Crustacea: Oniscidea). Terrestrial Arthropods Reviews, 1: 95-110.

LARDIES, M. A., I. S. COTORAS, F. BOZINOVIC, 2004 - The energetics of reproduction and parental care in terrestrial isopod Porcellio laevis. Journal of Insect Physiology, 50: 11281135 . 
LAWLOR, L. R., 1976 - Molting, growth and reproductive strategies in the terrestrial isopod, Armadillidium vulgare. Ecology, 57: 1179-1194.

MAGURA, T., B. TÓTHMÉRÉSZ, ZS. BORDÁN, 2000 - Effects of nature management practice on carabid assemblages (Coleoptera: Carabidae) in a non-native plantation. Biological Conservation, 93: 95-102.

MILLER, R. H., G. N. CAMERON, 1983 - Intraspecific variation of life history parameters in the terrestrial isopod, Armadillidium vulgare. Oecologie, 57: 216-226.

OBERFRANK, A., A. VÉGH, Z. LANG, E. HORNUNG, 2011 - Reproductive strategy of Protracheoniscus politus (C. Koch, 1841) (Oniscidea: Crinocheta: Agnaridae). Pp. 135-136. In: P. Zidar, J. Strus (eds), Proceedings of the 8th International Symposium of Terrestrial Isopod Biology, Bled, Slovenia.

PARIS, O. H., F. R. PITELKA, 1962 - Population characteristics of the terrestrial isopod Armadillidium vulgare in California grassland. Ecology, 43 (2): 229-248.

QUADROS, A. F., Y. CAUBET, P. B. ARAUJO, 2009 - Life history comparison of two terrestrial isopods in relation to habitat specialization. Acta Oecologica 35: 243-249.

RADU, V. GH., 1985 - Ordinul Isopoda, Subordinul Oniscoidea, Crinochaeta. In: Fauna Republicii Socialiste România, Crustacea, 4 (14): 1-158. [Fauna of Romania, Crustacea, Volume IV, Fascicle 14, Order Isopoda, Suborder Oniscoidea, Crinochaeta]. Edit. Academiei Republicii Socialiste România, Bucureşti. (in Romanian)

RADU, V. GH., N. TOMESCU, 1971 - Reproduction and ontogenetic development in Trachelipus balticus Verh., 1907. Revue Romaine de Biologie, Zoologie, 16: 89-96.

RADU, V. GH., N. TOMESCU, 1972 - Studiul populaţiei de Protracheoniscus politus-Koch (Crustacea-Izopode) dintr-o pădure de foioase [The study of a Protracheoniscus politusKoch (Crustacea-Isopoda) population from a deciduous forest]. Studia Universitatis BabeşBolyai, Biologia: 75-82. (in Romanian)

SCHMIDT, C., 1997 - Revision of the European species of the genus Trachelipus Budde-Lund, 1908 (Crustacea: Isopoda: Oniscidea). Zoological Journal of the Linnean Society, 121: 199-244.

TOMESCU, N., 1973 - Reproduction and postembryonic ontogenetic development in Ligidium hypnorum (Cuvier) and Trichoniscus pusillus (Brandt 1833) (Crustacea, Isopoda). Revue Romaine de Biologie, Zoologie, 18: 403-413.

TOMESCU, N., 1976 - Reproduction et development ontogénétique post-embryonnaire chez Hyloniscus transsylvanicus Verh. 1901 (Crustacea, Isopoda). Studia Universitatis BabeşBolyai, Biologia, 21: 44-48.

TOMESCU, N., C. CRĂCIUN, 1987 - Postembrionic ontogenetic development in Porcellio scaber (Crustacea: Isopoda). Pedobiologia, 30: 345-350.

TOMESCU, N., S. ACCOLA, C. BERCIU, 1992 - Reproduction of terrestrial isopods of Cheile Turzii Natural Reservation (Romania). Studia Universitatis Babeş-Bolyai, Biologia, 37: 39-45.

TOMESCU, N., S. ACCOLA, C. PAŞCA, 1995 - Ecology of the populations of terrestrial isopods (Crustacea: Isopoda) in Cheile Turzii. Studia Universitatis Babeş-Bolyai, Biologia, 40: 7894.

TOMESCU, N., G. ARDELEAN, D. MUREŞAN, V. POPA, 2000 - Ecology of terrestrial isopods in the Nature Reserve Scăriţa-Belioara, România. Studia Universitatis Babeş-Bolyai, Biologia, 45 (1): 57-64.

TOMESCU, N., D. MUREŞAN, L. OLARIU, R. HOTEA, 2005 - Terrestrial isopod communities (Crustacea, Isopoda) in riverside coppices and meadows of mountainous, hilly and depression areas. Studia Universitatis Babeş-Bolyai, Biologia 50 (2): 19-25.

TOMESCU, N., H. BOGDAN, V. I. PETER, S. D. COVACIU-MARCOV, I. SAS, 2008 - Terrestrial isopods from western and north-western Romania. Studia Universitatis Babeş-Bolyai, Biologia, 53 (2): 3-15. 
WARBURG, M. R., 1987 - Isopods and their terrestrial environment. Advances in Ecological Research, 17: 187-242.

WARBURG, M. R., 1994 - Review of recent studies on reproduction in terrestrial isopods. Invertebrate Reproduction and Development, 26 (1): 45-62.

ZIMMER, M., 2002 - Nutrition in terrestrial isopods (Isopoda: Oniscidea): an evolutionary-ecological approach. Biology Review, 77: 455-493.

ZIMMER, M., 2004 - Effects of temperature and precipitation on a flood plain isopod community: a field study. European Journal of Soil Biology, 40:139-146.

Received: March 9, 2011

Accepted: December 14, 2011
Ecological University of Bucharest, Faculty of Ecology and Environmental Protection

$1 G$ Vasile Milea Blvd., 061341 Bucharest, Romania

e-mail: finica_ivanov@yahoo.com 